\title{
ПОРІВНЯЛЬНИЙ АНАЛІЗ ПРОФІЛЮ ЕФЕКТИВНОСТІ ТА БЕЗПЕКИ ЕРДОСТЕЇНУ, КАРБОЦИСТЕЇНУ ТА N-АЦЕТИЛЦИСТЕЇНУ ПРИ ХРОНІЧНОМУ ОБСТРУКТИВНОМУ ЗАХВОРЮВАННІ ЛЕГЕНЬ \\ (за матеріалами статті Rogliani P, Matera MG, Page C, et al. Efficacy and safety profile of mucolytic/ antioxidant agents in chronic obstructive pulmonary disease: a comparative analysis across erdosteine, carbocysteine, and $\mathrm{N}$-acetylcysteine. Respiratory Research. 2019;20:104)
}

Пацієнтам із хронічним обструктивним захворюванням легень (ХОЗЛ) рекомендується регулярне лікування муколітичними/антиоксидантними препаратами, такими як ердостеїн, карбоцистеїн та $\mathrm{N}$-ацетилцистеїн (NAC) [1]. Фактично, в документі Глобальної Ініціативи щодо хронічного обструктивного захворювання легень (GOLD) вказується, що муколітичні/антиоксидантні препарати можуть знижувати ризик гострого погіршення ХОЗЛ (загострення ХОЗЛ) та покращувати стан здоров'я [1].

До 2015 року не було даних про точне визначення цільової популяції пацієнтів для застосування муколітичних/антиоксидантних препаратів при ХОЗЛ [2, 3], а останній, попередньо не заданий ретроспективний аналіз дослідження PANTHEON (Плацебо-контрольоване дослідження ефективності та безпеки високих доз $\mathrm{N}$-ацетилцистеїну при загостреннях хронічного обструктивного захворювання легень) (Placebo-controlled study on efficAcy and safety of $\mathrm{N}$-acetylcysTeine High dose in Exacerbations of chronic Obstructive pulmoNary disease) надав суперечливі докази щодо впливу терапії інгаляційними кортикостероїдами (IKC) та звички до паління на захисний ефект високих доз NAC проти ризику загострення ХОЗЛ [4]. І навпаки, кількісний синтез рандомізованих контрольованих досліджень (РКД), проведений відповідно до настанови «Переважні повідомлення про результати досліджень для систематичних оглядів і мета-аналізів» (Preferred Reporting Items for Systematic Reviews and Meta-Analyses) (PRISMA), за допомогою мета-регресійного аналізу, продемонстрував, що єдині фактори, які можуть суттєво вплинути на ефективність муколітичних/антиоксидантних препаратів при ХОЗЛ, це якість РКД, тривалість лікування та кількість загострення ХОЗЛ за рік, який передував зарахуванню для участі в дослідженні [5]. Цікаво, що останнє дослідження «Зменшення загострень і симптомів шляхом лікування пероральним ердостеїном при ХОЗЛ» (RESTORE) [6] продемонструвало, що ердостеїн був ефективним для зниження частоти та тривалості загострення ХОЗЛ незалежно від тяжкості випадку та супутнього лікування IKC.

На сьогодні не проводилося прямих порівняльних РКД для прямого порівняння профілю ефективності ердостеїну, карбоцистеїну та NAC. Отже, на суперечливі докази, отримані в результаті базових РКД муколітич-

www.search.crossref.org

DOI: 10.31215/2306-4927-2020-109-3-47-50 них/антиоксидантних препаратів при ХОЗЛ [7-10], а також нещодавню публікацію дослідження RESTORE [6], проведено парний та мережевий мета-аналіз наявних на сьогоднішній день даних із метою порівняння ефективності ердостеїну, карбоцистеїну та високих доз NAC.

\section{Матеріали та методи}

\section{Вибір досліджень}

У цей мета-аналіз були включені опубліковані РКД за участю пацієнтів, що отримували лікування протягом понад 6 місяців пероральними препаратами ердостеїну 600 мг/добу, карбоцистеїну 1500 мг/добу та NAC 1200 мг/ добу.

\section{Кінцеві точки}

Первинною кінцевою точкою цього мета-аналізу був вплив ердостеїну 600 мг/добу, карбоцистеїну 1500 мг/ добу та NAC 1200 мг/добу на зниження ризику загострення ХОЗЛ, порівняно з плацебо та для кожного активного лікарського засобу.

Вторинні кінцеві точки включали вплив ердостеїну 600 мг/добу, карбоцистеїну 1500 мг/добу та NAC 1200 мг/ добу на ризик виникнення щонайменше одного загострення ХОЗЛ, тривалість загострення ХОЗЛ і ризик госпіталізації внаслідок загострення ХОЗЛ, порівняно 3 плацебо. Іншою вторинною кінцевою точкою була частота небажаних явищ (НЯ).

\section{Оцінка якості, ризик похибки та профіль доказової бази}

Шкала оцінки Джадада (Jadad) від 1 до 5 (де оцінка 5 означає найвищу якість) використовувалася для оцінки якості РКД відносно ймовірності похибок, пов'язаних із рандомізацією, подвійним засліпленням, вилученням та вибуттям [16]. Оцінка $\geq 3$ за шкалою Джадада була визначена для ідентифікації високоякісних досліджень

\section{Аналіз даних}

Парний мета-аналіз був проведений для кількісного визначення впливу ердостеїну 600 мг/добу, карбоцистеїну 1500 мг/добу та NAC 1200 мг/добу на первинні та вторинні кінцеві точки, порівняно з плацебо.

Результати парного метааналізу виражаються як відносний ризик (ВР) або різниця середніх значень (РС), і $95 \%$ довірчий інтервал (95\% ДІ). Оскільки дані були відібрані з ряду досліджень, проведених дослідниками, 
що працюють незалежно, і загального розміру ефекту не можна припустити, була використана бінарна модель 3 випадковими ефектами, щоб врівноважити вагу досліджень та адекватно оцінити $95 \%$ ДІ середнього розподілу впливу лікарських засобів на досліджувані змінні [16].

Також був проведений мережевий мета-аналіз для порівняння між досліджуваними препаратами 3 точки зору первинної кінцевої точки та для ранжування їх ефекту для зниження ризику загострення ХОЗЛ. Мережевий мета-аналіз здійснювався шляхом використання виключно високоякісних РКД, які не внесли ні гетерогенності, ні похибки в загальну оцінку ефекту первинної кінцевої точки. Оскільки гетерогенність і похибка можуть поширюватися через мережу РКД і в такий спосіб по-різному впливати на оцінки в різних регіонах мережі, цей підхід дозволив визначити ті дослідження, які можуть змінити правильні результати мережевого мета-аналізу [25].

\section{Результати}

Проведено аналіз результатів лікування 2753 хворих на ХОЗЛ (11,15\% пацієнтів отримували ердостеїн, 18,27 \% - карбоцистеїн, 20,41 \% - NAC, і 50,16 \% плацебо), які були вибрані з 7 РКД [6-10, 35, 36], що опубліковані у період з 2004 по 2017 рік.

\section{Первинна кінцева точка}

Парний мета-аналіз показав, що і ердостеїн, i карбоцистеїн, і NAC достовірно знижують ризик виникнення загострення ХОЗЛ. На загальну оцінку ефекту вплинула висока та значна гетерогенність, що зумовлена дослідженнями карбоцистеїну та NAC. I навпаки, оцінка ефекту для ердоцистеїну не мала жодної гетерогенності (рис. 1А).

Аналіз чутливості показав, що основним джерелом гетерогенності $\epsilon$ дослідження карбоцистеїну Tatsumi et al. i Yasuda et al. [35, 36], оскільки при виключенні цих РКД загальна гетерогенність знизилися до прийнятних та незначущих рівнів $\left(I^{2}-26 \%, p>0,05\right)$ (рис. 1B). Тим не менш, візуальна перевірка воронкоподібного графіка вказувала, що дослідження Tse et al. [8] ввело певний рівень похибки публікації (рис. 1С). Насправді тест Еггера показав, що на результати аналізу чутливості вплинула значна похибка публікації, оскільки лінія регресії та $90 \%$ довірчі діапазони не перехопили вихідну точку графіка (рис. 1D). Подальший аналіз чутливості підтвердив, що дослідження Tse et al. [8] було джерелом похибки публікації, оскільки лінія регресії та 90 \% довірчі діапазони тесту Еггера перехопили вихідну точку графіка (Ү-перехоплення -1,64, від -6,23 до 3,00), коли це РКД [8] було вилучено з аналізу.

Мережевий мета-аналіз вказував, що ердостеїн був найбільш ефективним препаратом для попередження ризику загострення ХОЗЛ (верхній квартиль у ранжуванні SUCRA), за ним карбоцистеїн і NAC (третій квартиль у ранжуванні SUCRA) (рис. 1E).

Аналіз узгодженості/неузгодженості показав, що всі точки адекватно відповідають лінії рівного розподілу (ступінь приближення: $\mathrm{R}^{2}-0,99 ;$ нахил - 0,96; $95 \%$ Дl; 0,90-1,02), що свідчить про те, що на мережевий мета-аналіз не впливала значна похибка.

A

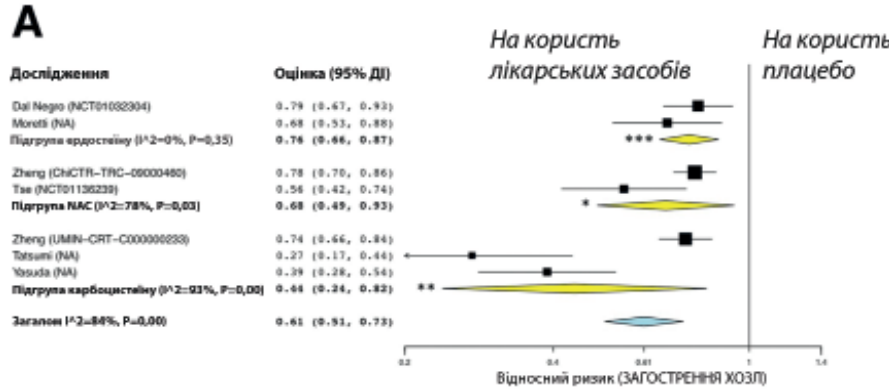

B
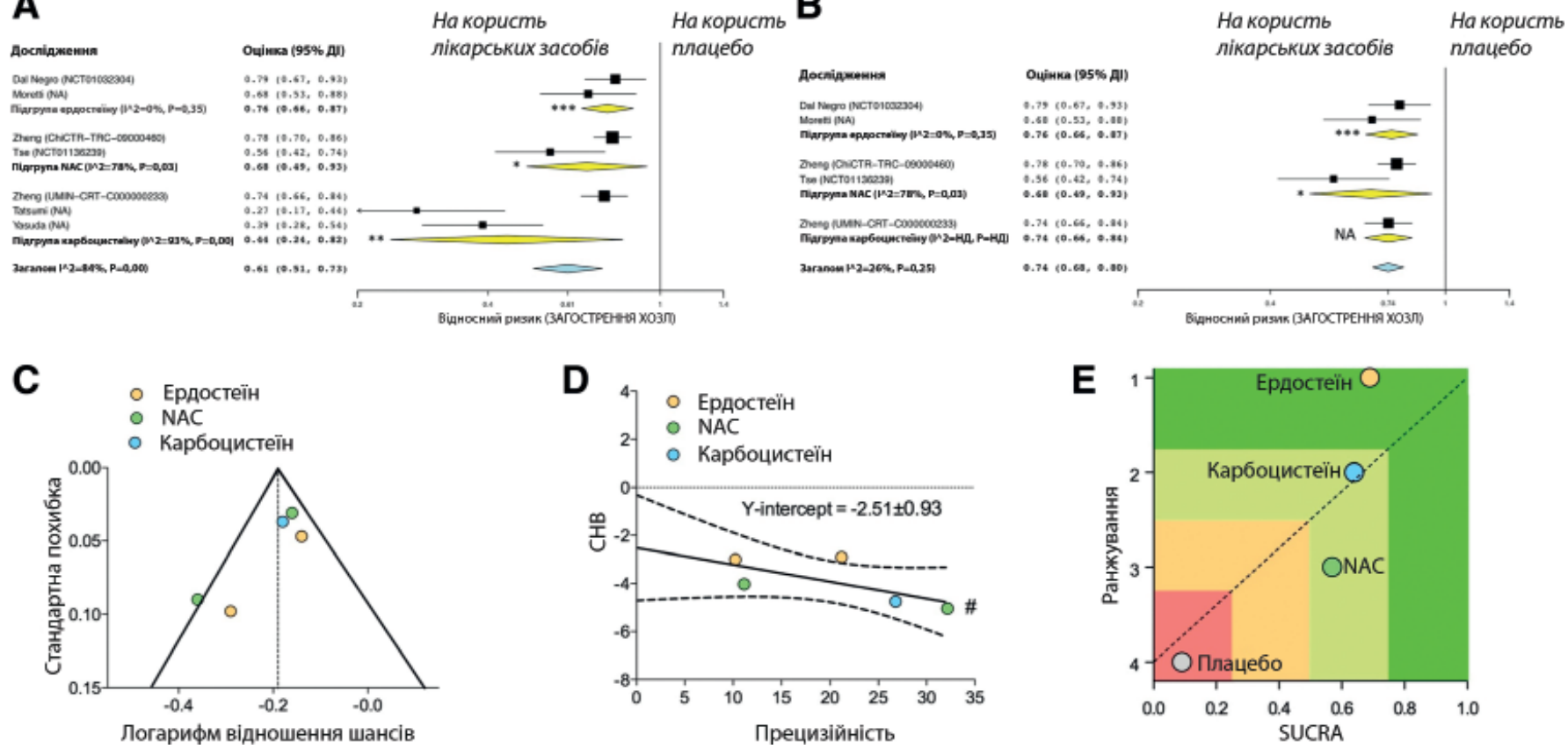

Рис. 1. Форест-діаграма парного мета-аналізу первинних кінцевих точок: вплив ердостеїну, карбоцистеїну та NAC на ризик ЗАГОСТРЕННЯ ХОЗЛ порівняно з плацебо (A); аналіз чутливості, проведений методом виключення досліджень, які вносили значну гетерогенність у загальну оцінку ефекту (B); оцінка похибки публікації через воронкоподібний графік (C) тест Еггера (D); графік ранжування, отриманий в результаті мережевого мета-аналізу, в якому дані про лікарські засоби наносили на вісь X відповідно до SUCRA (при цьому оцінка 1 означає найвищу ефективність) та на вісь Y відповідно до ранжування найкращого лікарського засобу (при цьому очінка 1 означає найвищу ефективність) (E). \# -p<0,1,* - p $<0,05, * *$ $-p<0,01 i^{* * *}-p<0.001$. ЗАГОСТРЕННЯ ХОЗЛ - гостре погіршення ХОЗЛ, ХОЗЛ - хронічне обструктивне захворювання легень, НД - недоступно, NAC - N-ацетилцистеїн, CHB - стандартне нормальне відхилення, SUCRA - поверхня під кривою сукупного ранжування. 
Сукупний аналіз НЯ, вилучених з досліджень ердостеїну, карбоцистеїну та NAC у хворих на ХОзЛ та класифікованих за частотою відповідно до настанов ЕМА [37]

\begin{tabular}{|c|c|c|c|}
\hline & Ердостеїн & Карбоцистеїн & NAC \\
\hline Загальна кількість суб'єктів & 354 & 557 & 553 \\
\hline Частота (\%) всіх НЯ & 1,32 & 2,26 & 18,26 \\
\hline $\begin{array}{l}\text { Частота (\%) специфічних НЯ: } \\
\text { інфекція дихальних шляхів }\end{array}$ & $\mathrm{HB}$ & 0,56 & 10,85 \\
\hline порушення з боку ШКТ & 0,44 & 1,13 & 4,16 \\
\hline свербіж & $\mathrm{HB}$ & $\mathrm{HB}$ & 1,08 \\
\hline запаморочення & $\mathrm{HB}$ & $\mathrm{HB}$ & 0,72 \\
\hline порушення з боку кістково-м'язової системи & $\mathrm{HB}$ & 0,28 & 0,54 \\
\hline порушення з боку печінки та жовчовивідних шляхів & 0,44 & $\mathrm{HB}$ & $\mathrm{HB}$ \\
\hline нездужання & $\mathrm{HB}$ & 0,28 & $\mathrm{HB}$ \\
\hline безсоння & $\mathrm{HB}$ & $\mathrm{HB}$ & $\mathrm{HB}$ \\
\hline посилення кашлю & $\mathrm{HB}$ & $\mathrm{HB}$ & $\mathrm{HB}$ \\
\hline
\end{tabular}

Примітка: ++++:дуже часті ( $\geq 1 / 10) ;+++$ часті (від $\geq 1 / 100$ до <1/10);++: нечасті (від $\geq 1 / 1000$ до < 1/100); +: рідкісні (від $\geq 1 / 10000$ до < 1/1000); НЯ - небажані явища; ХОЗЛ - хронічне обструктивне захворювання легень; EMA - Європейське агентство лікарських засобів; NAC - N-ацетилцистеїн; $\mathrm{HB}$ - не визначено (частота невідома).

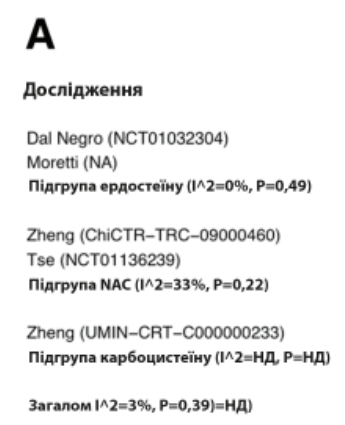

B

Дослідження
Dal Negro (NCT01032304)
Moretti (NA)
Miдrpyna epдостеїнy $((\wedge 2=59 \%, \mathrm{P}=0,12)$
Zheng (ChiCTR-TRC-09000460)
Tse (NCT01136239)
חiдrpyna NAC ( $(\wedge 2=17 \%, \mathrm{P}=0,27)$
3aranom $1 \wedge 2=63 \%, \mathrm{P}=0,05)$

\section{C}

Дослідження

Dal Negro (NCT01032304) Moretti (NA)

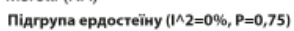

Zheng (ChiCTR-TRC-09000460) Tse (NCT01136239)

Miarpyna NAC (1^2=30\%, P=0,23)

$3 a \sin \left(\ln _{2}=0 \%, \mathrm{P}=0,49\right)$
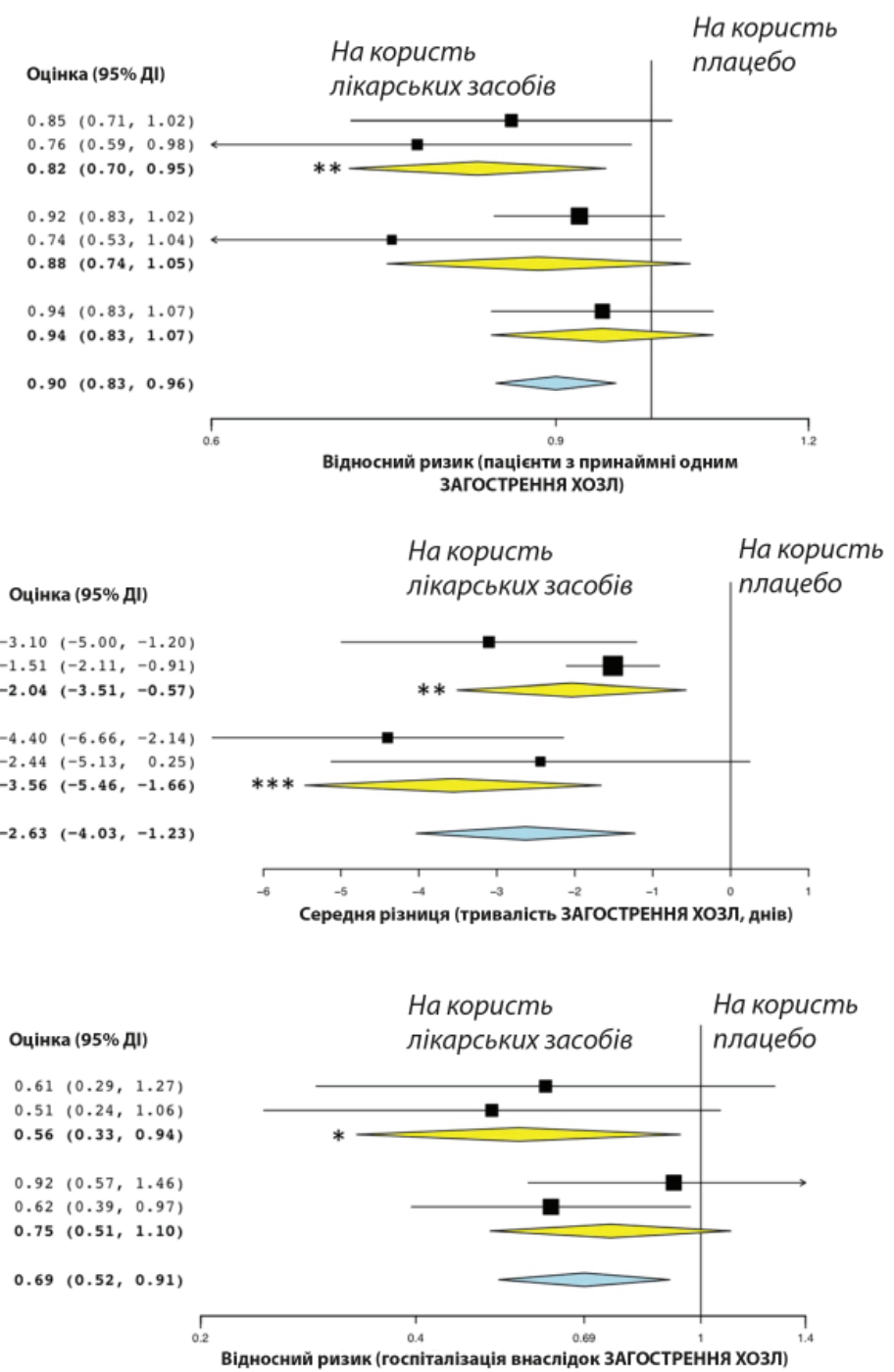

Pис. 2. Форест-діаграма парного мета-аналізу вторинних кінцевих точок: вплив ердостеїну, карбоцистеїну та NAC на ризик виникнення принаймні одного ЗАГОСТРЕННЯ ХОЗЛ (А), тривалість ЗАГОСТРЕННЯ ХОЗЛ (В) і рИзИк госпіталізації внаслідок ЗАГОСТРЕННЯ ХОЗЛ (C), порівняно з плацебо. * - $p<0,05 i$ * - $<<0,01$. ЗАГОСТРЕННЯ ХОЗЛ - гостре погіршення ХОЗЛ, ХОзЛ - хронічне обструктивне захврювання легень. 
Аналіз NNT на основі особи свідчив, що 10,11 (95 \% Дl; 5,41-76,39) пацієнтів необхідно пролікувати ердостеїном протягом одного року для попередження одного випадку загострення ХОЗЛ, порівняно з плацебо ( $><0,05)$. І навпаки, значення NNT як для карбоцистеїну (30,92; 95\%

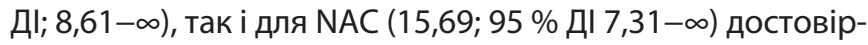
но не відрізнялися ( $p>0,05)$ від плацебо.

Аналіз GRADE вказував на високу якість доказової бази (++++) для ердостеїну, низьку якість доказової бази $(++)$ для карбоцистеїну та середню якість доказової бази (+++) для NAC, порівняно з плацебо. Якість доказової бази при мережевому мета-аналізі з порівняння ердостеїну, карбоцистеїну та NAC через групу плацебо була середньою (+++).

\section{Вторинні кінцеві точки}

Ердостеїн, на відміну від карбоцистеїну та NAC, достовірно ( $p<0,01)$ знижує ризик виникнення принаймні одного загострення ХОЗЛ, порівняно з плацебо (рис. 2A). Ердостеїн, на відміну від NAC, достовірно $(\mathrm{p}<0,05)$ знижував ризик госпіталізації внаслідок загострення ХОЗЛ, порівняно з плацебо; для карбоцистеїну наразі немає даних щодо цього наслідку (рис. 2С).

Найбільш частим НЯ була інфекція дихальних шляхів (NAC: 10,85 \%, карбоцистеїн: 0,56 \%, ердостеїн: не виявлено), а детальні дані щодо частоти інших специфічних НЯ наведені в таблиці.

\section{Обговорення}

У цьому кількісному синтезі поточної літератури як ердостеїн, так і карбоцистеїн, і NAC відповідали первинній кінцевій точці, представленій зниженням ризику загострення ХОЗЛ. Розглядаючи виключно високоякісні РКД, які не ввели значущої гетерогенності в парний мета-аналіз, це дослідження вказує на те, що середня оцінка ефекту загального впливу муколітичних/антиоксидантних препаратів досягла мінімальної клінічно важливої різниці (MCID: $\approx 0,75$ BP) $[19,38]$ при зниженні ризику загострення ХОЗЛ порівняно з плацебо. В будь-якому випадку, схоже, що на результати парного мета-аналізу впливає певний рівень похибки публікації, яка була переважно пов'язана з результатами, вилученими $з$ дослідження Tse et al. [8], що підтверджується аналізами як воронкоподібного графіка, так і тесту Еггера.

Хоча не виявлено значущої різниці між досліджуваними лікарськими засобами з точки зору їх захисного ефекту проти загострення ХОЗЛ, аналіз SUCRA, отриманий в результаті мережевого мета-аналізу, вказував на те, що ердостеїн $\epsilon$ найбільш ефективним препаратом, за ним - карбоцистеїн і NAC. Цікаво, що аналіз узгодженості/неузгодженості продемонстрував, що значуща похибка не вплинула на мережевий мета-аналіз.

Стосовно вторинних кінцевих точок, тільки ердостеїн був достовірно ефективним у зниженні ризику виникнення принаймні одного загострення ХОЗЛ і ризику госпіталізації внаслідок загострення ХОЗЛ, в той час як тривалість загострення ХОЗЛ скорочувалася завдяки як ердостеїну, так і NAC.

\section{Висновок}

Сучасні дані свідчать про те, що загальний профіль ефективності/безпеки ердостеїну перевершує такий профіль для карбоцистеїну та NAC. Тим не менш, потрібні подальші прямі порівняльні дослідження, проведені у тих самих популяціях хворих на ХОЗЛ, для остаточного підтвердження результатів цього кількісного синтезу.

Матеріал підготовлений для публікації доктором мед. наук С. І. Лещенко (ДУ «Національний інститут фттизіатрії і пульмонології ім. Ф. Г. Яновського НАМН України). Список літератури знаходиться у редакції. 